Article

\title{
Centralized or Decentralized Rainwater Harvesting Systems: A Case Study
}

\author{
Daniel Słyś(i) and Agnieszka Stec *(i) \\ Department of Infrastructure and Water Management, Rzeszow University of Technology, \\ 35-959 Rzeszów, Poland; daniels@prz.edu.pl \\ * Correspondence: stec_aga@prz.edu.pl
}

Received: 29 November 2019; Accepted: 9 January 2020; Published: 12 January 2020

\begin{abstract}
World population growth, climate changes, urbanization, and industrialization have all had a negative impact on natural resources, including water resources. Excessive exploitation and pollution have caused more and more regions to have problems with access to fresh water. Rainwater is perceived as a valuable alternative source of water that is most often used in a hybrid system supplementing tap water. Considering the possibilities of designing a rainwater harvesting system as a decentralized or central system, this research was undertaken to determine the hydraulic and financial efficiency of these two systems. The research was carried out for a single-family housing estate located in Poland. For this research, a simulation model was applied to determine the efficiency of water saving and the life cycle cost indicator. In variants where rainwater was only used to flush toilets, the water saving efficiency was $80 \%$ and $79 \%$ for the decentralized and centralized rainwater harvesting system (RWHS), respectively. The use of rainwater for toilet flushing and watering the garden resulted in a significant reduction in efficiency to $57 \%$ (the decentralized system) and $54 \%$ (the centralized system). On the other hand, the results of the life cycle cost (LCC) analysis showed that in spite of reducing tap water consumption, both the centralized and the decentralized rainwater harvesting system were not financially viable solutions for the housing estate, and only cofinancing investments at the level of $25 \%$ to $50 \%$ resulted in a significant improvement in financial efficiency.
\end{abstract}

Keywords: alternative water resources; rainwater harvesting; life cycle cost; financial efficiency; water saving

\section{Introduction}

Over the last century, there has been a rapid development of cities and urbanization of areas that were previously of a natural or rural nature. Europe has evolved into a continent where about $73 \%$ of the population lives in urban areas [1], and only North America $(82 \%)$ and South America $(80 \%)$ belong to more urbanized continents.

An increase in the population that is concentrated in small spaces and the development of industry and communication, as well as the pursuit of raising living standards have caused a significant depletion of natural resources, including surface and underground water resources [2]. These factors, as well as economic and political problems related to water, are the main reasons for the lack of water security in the world [3]. Climate changes are also observed, which are increasingly affecting all aspects of the lives of people, including the availability of potable water. Therefore, optimal management of available water resources is necessary to deal with all these problems [4]. Sustainable urban water management has become a goal of strategic planning for water utilities [5]. Access to an adequate quality of water, including the quality supplied from a water supply network, is a basic need for human development. Failure to meet the required potable water quality standards threatens the safety of water system users and reduces the reliability of the potable water $[6,7]$. 
In response to such significant and largely irreversible changes that occur in the environment and take place as a result of urbanization and industrialization, there have also been changes in the construction sector [8]. Different solutions have been aimed at fundamentally changing the environment by creating energy-conscious, healthy, and sustainable buildings that have negligible impact on urban life and the natural environment [9-11]. This applies to the materials used to make a building and the installations a building is equipped with.

Therefore, especially in urban areas, some actions have been taken which aim to introduce and implement sustainable water and wastewater management [12]. The overriding goal of these strategies is to maintain water resources in good condition and to exploit them at such a level that economic and social development is possible for current and future generations [13,14]. Hence, the problems of obtaining energy and water from alternative sources are becoming increasingly important $[15,16]$. This is particularly significant in the case of residential construction for which it has been estimated that the use of freshwater is about $10 \%$ of the total global water demand [17].

When considering alternative water sources, special attention is paid to rainwater, which in most cases is characterized by a low degree of pollution which does not require advanced purification processes $[18,19]$. However, its quality depends on many factors, including air quality, the type of catchment management, the type of roof coverage and its decline [20-22]. Rainwater is an important alternative to tap water. It can be used as potable water in areas with low water resources, and, in the case of other areas, for economic applications [23] as water with reduced quality parameters. In most countries in the world, a rainwater harvesting system (RWHS) is used mainly as a complementary system to conventional water sources for non-potable use, especially for toilet flushing, cleaning work, washing, irrigation of green areas, and farmland [24-28]. Rainwater harvesting systems are created as decentralized systems [29,30], i.e., belonging to individual buildings or systems for central collection and management of rainwater [31]. The decentralized systems are used in the vast majority of cases worldwide.

Implementation of RWHSs on a larger scale, in addition to reducing tap water consumption, can also have a positive effect on sewer systems and reduce the occurrence of urban floods [32-34]. This is very important from the point of view of the design and operation of drainage infrastructure, which is the most capital-intensive sewer system $[35,36]$.

Applications of RWHS systems in various regions of the world depend on many local factors which include the abundance of conventional water sources, climatic conditions (height and frequency of precipitation), social conditions, financial and institutional support, type of facilities, number of users, as well as the price of tap water, sewage, and energy [37-43]. These factors also affect the efficiency of tap water savings which can reach up to $90 \%$ of non-potable water demand for toilet flushing, laundry, and irrigation [44].

The choice of a rainwater harvesting system technical solution is important from an investor's point of view as it influences the financial results which are an important factor affecting the implementation of such systems in buildings. The application of a RWHS is subject to the same economical laws of profit and loss as other investments. Hence, there is a need to perform technical and economic analyses in the decision-making process [45], especially the life cycle cost (LCC) analysis, which takes into account all costs throughout the lifetime of the facility [46].

In Poland, despite the fact that potable water resources are one of the poorest in Europe, and that potable water resources amount to only $1100 \mathrm{~m}^{3}$ /person/year in dry years [47], RWHSs are not a very popular water saving strategy, especially the centralized rainwater harvesting systems. This is due mainly to insufficient public awareness, the lack of explicit legal regulations, insufficient information campaigns, and the lack of financial incentives, as well as the conviction by millions of people that Poland has rich water resources that are inexhaustible. However, some researchers have emphasized that social campaigns are insufficient, and future actions should focus on specific policy decisions and water management practices [48]. Forecasts for Poland are not optimistic, especially in terms of the impact of predicted climate change on water resources that could contribute to diminishing levels of 
water availability in coming years and eventually lead to a deterioration of the quality of life for future generations [49]. Currently, the average annual resources per one Pole are estimated at about $1600 \mathrm{~m}^{3}$, which accounts for only $35 \%$ of the resources per statistical inhabitant of Europe.

Previous publications on the use of rainwater in Poland for various buildings and various technical parameters of installations have concerned RWHSs which have been installed as decentralized systems [50,51]. There is no scientific research related to centralized systems. In addition, in other countries, this type of rainwater harvesting system is very rarely included in the scientific studies of various researchers.

Considering the above, this research was undertaken to assess the potential of reducing potable water consumption in a housing estate by using rainwater in decentralized and centralized systems, which is a novelty not only in Poland, but worldwide. Analyses of hydraulic, technical, and financial conditions for four variants of the rainwater harvesting system were performed using the example of a single-family housing estate located in Poland. The rainwater was intended for toilet flushing and watering the garden.

\section{Materials and Methods}

\subsection{Case Study}

The case study, for this research, concerns the housing estate "Słoneczna Aleja" (Sunny Avenue Estates) in Warsaw, Poland (Figure 1). The estate consists of 22 single-family houses made in skeleton technology as energy-efficient semi-detached buildings. The usable area of a single building is $135 \mathrm{~m}^{2}$. The horizontal projection surface of the roof is $85 \mathrm{~m}^{2}$. The undeveloped plot area is $235 \mathrm{~m}^{2}$.

Rainwater harvesting systems were considered as an additional installation for the buildings. For this purpose, technical, hydraulic and financial analyses of such an investment were performed. The calculations were carried out for the following investment options:

- Variant 0, no rainwater harvesting system and the water supply for the building only from the water supply system;

- Variant 1A, an individual (decentralized) system for collecting, storing, and using rainwater to flush toilets, supplementing water shortages from the water supply network;

- Variant $1 \mathrm{~B}$, an individual (decentralized) system for collecting, storing, and using rainwater for toilet flushing and irrigating the area, supplementing water shortages from the water supply network;

- Variant 2A, a centralized (joint) system for collecting and storing rainwater from all the buildings and its use for toilet flushing with additional water shortages from the water supply network;

- Variant 2B, a centralized (joint) system for collecting and storing rainwater from all the buildings and its use for toilet flushing and irrigating the area, supplementing water shortages from the water supply network. 

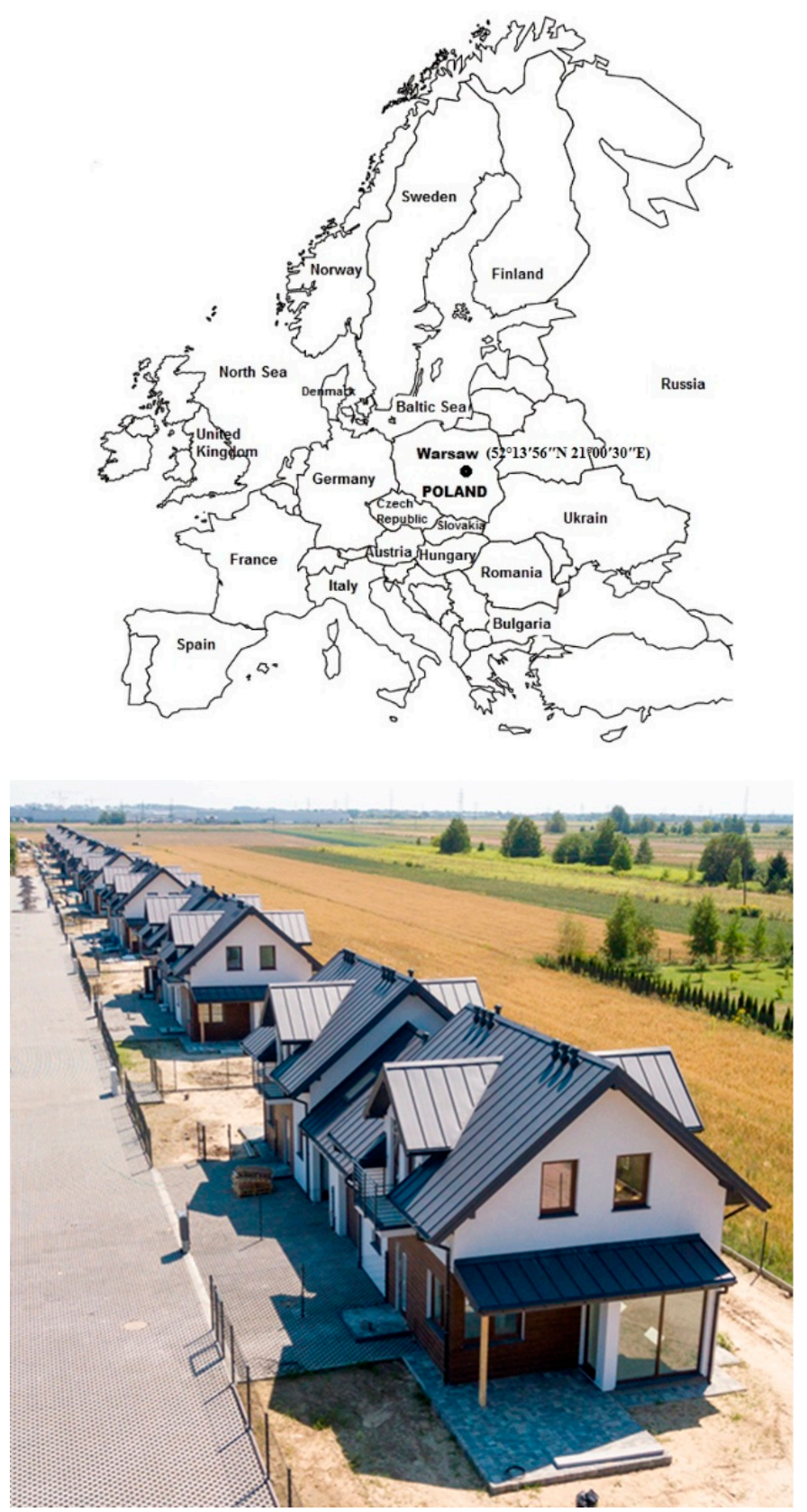

Figure 1. Location of a housing estate $\left(52^{\circ} 13^{\prime} 56^{\prime \prime} \mathrm{N} 21^{\circ} 00^{\prime} 30^{\prime \prime} \mathrm{E}\right)$.

The diagram of the rainwater harvesting system in Variants $1 \mathrm{~A}$ and $1 \mathrm{~B}$ and Variants $2 \mathrm{~A}$ and $2 \mathrm{~B}$ is shown in Figure 2.

The research assumed, on the one hand, that the demand for rainwater for toilet flushing was constant throughout the entire period of the analysis. This assumption was justified as the demand time series generated by the use of toilets did not show excessive daily differences [52]. On the other hand, the use of rainwater for irrigation of the area was periodic and, in Polish conditions in accordance with design guidelines [53], was carried out for 15 days during the spring and autumn months, from April 15 to September 15. The calculation parameters for buildings, plots of land, and RWHSs are presented in Table 1. The calculations assume the statistical number of people in the household for Poland [54]. 
a)

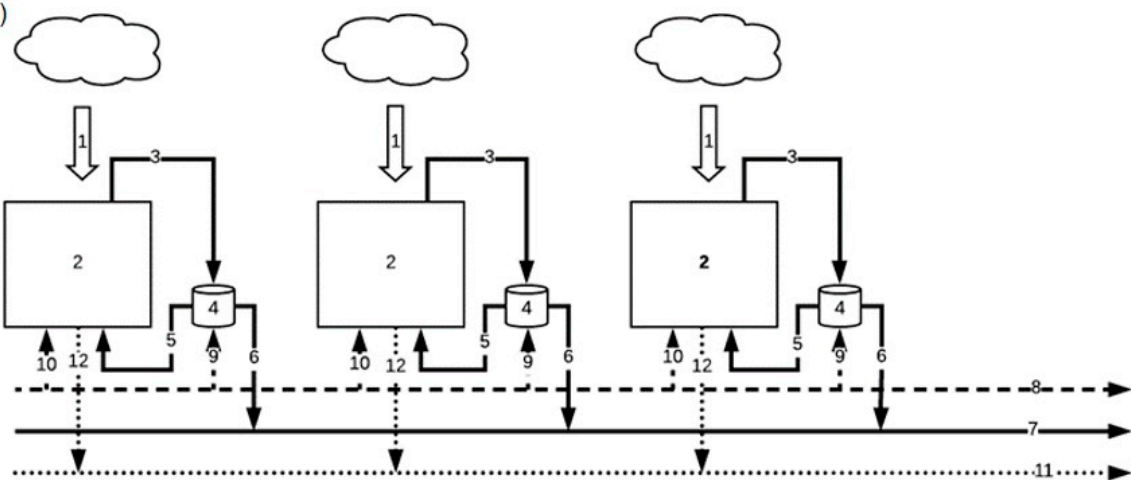

b)

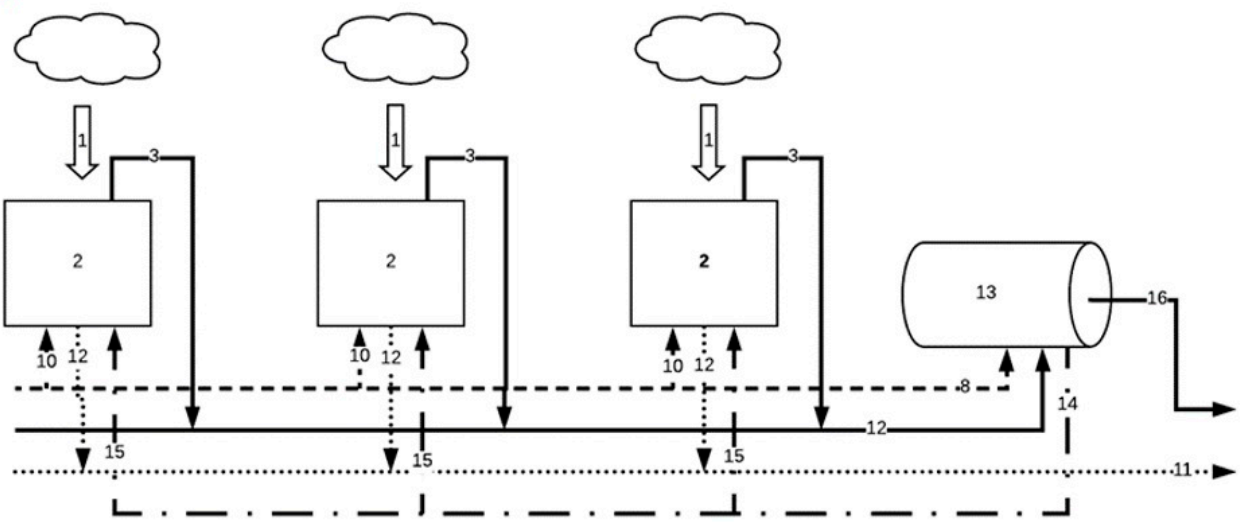

Figure 2. Scheme of rainwater harvesting system: (a) Variant $1 \mathrm{~A}$ and Variant $1 \mathrm{~B}$ and (b) Variant $2 \mathrm{~A}$ and Variant 2B. 1, precipitation; 2, building; 3, rainwater supply to the tank; 4, individual rainwater tank; 5, rainwater supply from the individual tank to the building; 6 , excess rainwater discharge from the individual tank; 7 , rainwater drainage system; 8 , water supply network; 9 , supply of tap water (supplementary) to the tank; 10, supply of tap water to the building; 11, sewage network; 12 , sewage drainage from the building; 13 , central rainwater tank; 14, rainwater distribution network; 15 , supply of rainwater from the network to the building; and 16, excess discharge of rainwater from the central tank.

Table 1. Calculation parameters of buildings, plots, and rainwater harvesting systems (RWHSs).

\begin{tabular}{|c|c|c|c|c|c|}
\hline \multirow{2}{*}{ Parameter } & \multicolumn{5}{|c|}{ Value } \\
\hline & Variant 0 & Variant 1A & Variant 1B & Variant 2A & Variant 2B \\
\hline Roof area, $\mathrm{m}^{2}$ & \multicolumn{5}{|c|}{$22 \times 85 \mathrm{~m}^{2}$} \\
\hline Garden surface, $\mathrm{m}^{2}$ & \multicolumn{5}{|c|}{$22 \times 235 \mathrm{~m}^{2}$} \\
\hline No. of occupants, person & \multicolumn{5}{|c|}{$22 \times 2.69$} \\
\hline $\begin{array}{l}\text { Average unit water demand } \\
\text { for toilet flushing } q_{w c} \\
\mathrm{~m}^{3} / \text { day/person }\end{array}$ & \multicolumn{5}{|c|}{0.035} \\
\hline $\begin{array}{l}\text { Average unit water demand } \\
\text { for area irrigation } \mathrm{q}_{\mathrm{ir}} \\
\mathrm{m}^{3} / \text { day } / \mathrm{m}^{2}\end{array}$ & - & - & 0.0025 & - & 0.0025 \\
\hline Period of area irrigation & - & - & $\begin{array}{c}15 \\
\text { April-15 } \\
\text { September }\end{array}$ & - & $\begin{array}{l}15 \text { April-15 } \\
\text { September }\end{array}$ \\
\hline Tank capacity, $\mathrm{m}^{3}$ & - & $1,2,3,4,5$ & $1,2,3,4,5$ & $15,30,45,60,75$ & $15,30,45,60,75$ \\
\hline
\end{tabular}


The simulation tests were carried out using real daily precipitation and temperature data, which were recorded at the Warsaw Okęcie meteorological station. The data from 2000 to 2013 were applied for this research. The average annual precipitation sums for this period are shown in Figure 3. In the period analyzed, the median annual precipitation sums for Warsaw was $581 \mathrm{~mm}$ and it did not differ significantly from the precipitation values from other long-term periods.

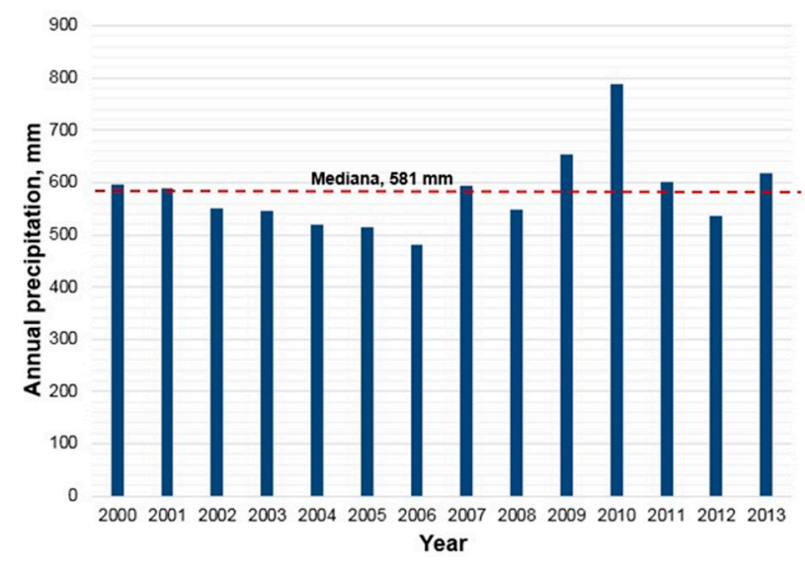

Figure 3. The amount of rainfall in the years 2000 to 2013.

\subsection{Hydraulic Analysis}

The hydraulic analysis of the rainwater harvesting system in the variants adopted was based on a simulation model based on daily mass water balance developed by Słyś [55], which can be generally described by Formula (1):

$$
\mathrm{V}_{\mathrm{i}}=\mathrm{I}_{\mathrm{i}}+\mathrm{V}_{\mathrm{i}-1}-\mathrm{U}_{\mathrm{i}}-\mathrm{Z}_{\mathrm{i}}
$$

where $V_{i}$ is the volume of rain water retained in the tank at the end of the $i$-day; $I_{i}$ is the volume of rain water flowing from the roof to the tank on the $\mathrm{i}$-th day, $\mathrm{m}^{3} ; \mathrm{V}_{\mathrm{i}-1}$ is the volume of rainwater remaining in the tank from the previous day, $\mathrm{m}^{3} ; \mathrm{U}_{\mathrm{i}}$ is the volume of rainwater collected on the $\mathrm{i}$-th day from the reservoir, $\mathrm{m}^{3}$; and $\mathrm{Z}_{\mathrm{i}}$ is the volume of excess rainwater discharged from the tank to the sewage system on the i-th day, $\mathrm{m}^{3}$.

The inflow of rainwater to reservoir $\mathrm{I}_{\mathrm{i}}$ depends on the roof surface, $\mathrm{A}$, and the amount of precipitation, $\mathrm{H}$, occurring on a given day. The size of the inflow is determined from Formula (2):

$$
\mathrm{I}_{\mathrm{i}}=\varphi \times \mathrm{A} \times \mathrm{H}_{\mathrm{i}}
$$

where $\varphi$ is the runoff coefficient, $A$ is the surface area, $\mathrm{m}^{2}$; and $\mathrm{H}_{\mathrm{i}}$ is the daily precipitation, $\mathrm{m}$.

The calculation also takes into account the type of precipitation (rain or snow) and atmospheric air temperature. During periods of snowfall its quantity is automatically converted to the amount of liquid precipitation. If the following two conditions are met: (i) the presence of snowfall and (ii) the air temperature below $0{ }^{\circ} \mathrm{C}$, the amount of precipitation is not included on a given day in the balance of water stored in the retention tank. This precipitation is taken into account on the following days when the air temperature is above $0{ }^{\circ} \mathrm{C}$. This assumption in the calculation model considers the occurrence of solid precipitation (snow) and negative temperatures that limit snow melting and water supply in the tank.

Due to the low pollution of rainwater coming from the roofs of buildings, the simulation model did not take into account the impact of these pollutants on the functioning of the system. This assumption is similar to the assumptions of other such computational models [56,57]. This model is very similar to other models such as the one developed by Fewkes [52]. The model algorithm is based on the YAS (yield after spillage) operating rule. The general principle of the YAS operation is as follows: The volume of rainwater supplied to the tank in the current time interval is added to the volume of 
rainwater remaining in the tank from the previous time interval, and the excess of water is removed by the overflow. The initial storage volume $\left(\mathrm{V}_{\mathrm{i}-1}\right)$ for the second time step is the volume of water at the end of the first step $\left(\mathrm{V}_{\mathrm{i}}\right)$. The daily time interval was used in these studies.

On the basis of the results obtained from the RWHS simulation tests, the efficiency of tap water saving, $E_{f}$, was determined from Formula (3) [55].

$$
\mathrm{Ef}=\frac{\sum_{\mathrm{i}=1}^{\mathrm{T}} \mathrm{U}_{\mathrm{i}}}{\sum_{\mathrm{i}=1}^{\mathrm{T}} \mathrm{J}_{\mathrm{i}} \times \mathrm{d}_{\mathrm{di}}} \times 100 \%
$$

where $U_{i}$ is the volume of rainwater collected on the $\mathrm{i}$-th day from the reservoir, $\mathrm{m}^{3} ; \mathrm{J}_{\mathrm{i}}$ is the number of system users on the $\mathrm{i}$-th day, person; and $\mathrm{d}_{\mathrm{di}}$ is the daily water demand for a specific purpose on the i-th day, $\mathrm{m}^{3} /$ person/day.

\subsection{Financial Analysis}

The test results based on the simulation model of rainwater harvesting systems (RWHS) were used as input to assess the financial efficiency of the investment regarding the possibility of using such systems in the area of the housing estate.

The financial analysis of the rainwater harvesting system was carried out using the life cycle cost (LCC) methodology. The value of the LCC indicator, which was determined from Formula (4), consists of the following: (i) $\mathrm{INV}_{\mathrm{k}}$ investments incurred for the purchase and installation of a given system, (ii) operating costs expected throughout its lifetime, $\mathrm{OC}_{\mathrm{k}}$, and (iii) costs of disposal, $\mathrm{MC}_{\mathrm{k}}$ [58]. Cash flows occurring in subsequent years are discounted, which allows for a comparison of their amounts appearing at different periods of time. The determination of the share of individual components in the total costs of the project is very important, both from the point of view of the investor and the system operator. The LCC enables cost optimization of investment projects [59] and the making of balanced decisions [60]. The guidelines contained in [61] studies provide that wherever the life span of an analyzed system goes beyond the foreseeable future, its residual value at the completion of exploitation do not need be defined in quantifiable terms. Consequently, the $\mathrm{MC}_{\mathrm{k}}$ costs were not taken care of in the quantitative analysis, similar to studies conducted by other authors [62].

$$
\mathrm{LCC}_{\mathrm{k}}=\mathrm{INV}_{\mathrm{k}}+\sum_{\mathrm{t}=1}^{\mathrm{T}} \frac{\mathrm{OC}_{\mathrm{kt}}}{(1+\mathrm{r})^{\mathrm{t}}}+\mathrm{MC}_{\mathrm{k}}
$$

where $\mathrm{T}$ is the duration of the LCC analysis, years; $\mathrm{r}$ is the fixed discount rate; and $\mathrm{t}$ is another year of using the installation.

The operating costs of the building water supply system can be calculated from Formula (5).

$$
\mathrm{OC}_{\mathrm{kt}}=\mathrm{WC}_{\mathrm{kt}}+\mathrm{SC}_{\mathrm{kt}}+\mathrm{RC}_{\mathrm{kt}}
$$

where $\mathrm{WC}_{\mathrm{kt}}$ is the cost of purchasing tap water in the $\mathrm{k}$ and year $\mathrm{t}$ option, $€ ; \mathrm{SC}_{\mathrm{kt}}$ is the sewage disposal costs in option $\mathrm{k}$ and year $\mathrm{t}, €$; and $\mathrm{RC}_{\mathrm{kt}}$ is the costs of rainwater drainage to the sewage system in the $\mathrm{k}$ and year option $\mathrm{t}, €$.

In the case of buildings without a RWHS, the value of the $\mathrm{WC}_{\mathrm{kt}}$ parameter can be calculated from Formula (6).

$$
\mathrm{WC}_{\mathrm{kt}}=\mathrm{D}_{\mathrm{t}} \times \mathrm{cW}_{\mathrm{t}}
$$

where $D_{t}$ is the water demand for specific purposes, $\mathrm{m}^{3} / \mathrm{year}$, and $\mathrm{cw}_{t}$ is the purchase price of tap water in year $\mathrm{t}, € / \mathrm{m}^{3}$.

However, for buildings additionally supplied with water from the RWHS system, the $\mathrm{WC}_{\mathrm{kt}}$ value is described by Formula (7).

$$
\mathrm{WC}_{\mathrm{kt}}=\left(\mathrm{D}_{\mathrm{t}}-\mathrm{UW}_{\mathrm{tk}}\right) \times \mathrm{cW}_{\mathrm{t}}
$$


where $\mathrm{UW}_{\mathrm{tk}}$ is the volume of rainwater used in the building for specified purposes, $\mathrm{m}^{3} /$ year.

The demand for water for a specific purpose can be determined from Formula (8).

$$
\mathrm{D}_{\mathrm{t}}=365.25 \times \mathrm{J} \times \mathrm{d}_{\mathrm{dt}}
$$

where $\mathrm{J}$ is the number of occupants, person and $\mathrm{d}_{\mathrm{dt}}$ is the average daily water demand for a specific purpose, $\mathrm{m}^{3} /$ person/day.

The costs of wastewater disposal are determined from Formula (9).

$$
\mathrm{SC}_{\mathrm{kt}}=\mathrm{B}_{\mathrm{t}} \times \mathrm{cb}_{\mathrm{t}}
$$

where $B_{t}$ is the volume of sewage discharged from the building, $\mathrm{m}^{3} /$ year and $\mathrm{cb}_{t}$ is the sewage disposal price, $€ / \mathrm{m}^{3}$.

However, in the case of using water for toilet flushing and washing, it is assumed that $B_{t}=D_{t}$, whereas in the case of using rainwater for works outside the facility (watering and utility works), the value of $B_{t}$ is calculated from Formula (10).

$$
B_{t}=D_{t}-E_{t}
$$

where $E_{t}$ is the volume of tap water discharged outside the sewage system, $\mathrm{m}^{3} /$ year.

The cost of rainwater drainage $\mathrm{RC}_{\mathrm{kt}}$ can be calculated from Formula (11).

$$
\mathrm{RC}_{\mathrm{kt}}=\mathrm{R}_{\mathrm{t}} \times \mathrm{cr}_{\mathrm{t}}
$$

where $R_{t}$ is the volume of rainwater discharged from the building to the drainage system, $\mathrm{m}^{3} /$ year and $\mathrm{cr}_{\mathrm{t}}$ is the price for draining rainwater, $€ / \mathrm{m}^{3}$.

The discount rate is a very important parameter affecting the final results. The discount rate was assumed to be $5 \%$, as it was used in calculations by Roebuck et al. [46], Morales-Pinzon et al. [63] and Rahman et al. [28].

Initial investments for the $\mathrm{INV}_{\mathrm{k}}$ variants were determined based on the information obtained from device manufacturers and contractors. The detailed summary of data for calculations is presented in Table 2. 
Table 2. Data used in the calculation of the life cycle cost (LCC) costs.

\begin{tabular}{|c|c|}
\hline Parameter & Parameter Value \\
\hline \multicolumn{2}{|l|}{ Investment Cost } \\
\hline Investments for Variant $0 \mathrm{INV}_{0}$ & $40,930 €$ \\
\hline $\begin{array}{c}\text { Investments } \mathrm{INV}_{1(1)} \text { for a tank with capacity } \mathrm{V}_{1(1)}=1 \mathrm{~m}^{3} \text { and dual water } \\
\text { supply installation }\end{array}$ & $2326 € \times 22=51,172 €$ \\
\hline $\begin{array}{c}\text { Investments } \mathrm{INV}_{1(2)} \text { for a tank with capacity } \mathrm{V}_{1(2)}=2 \mathrm{~m}^{3} \text { and dual water } \\
\text { supply installation }\end{array}$ & $2558 € \times 22=56,276 €$ \\
\hline $\begin{array}{c}\text { Investments } \mathrm{INV}_{1(3)} \text { for a tank with capacity } \mathrm{V}_{1(3)}=3 \mathrm{~m}^{3} \text { and dual water } \\
\text { supply installation }\end{array}$ & $2791 € \times 22=61,402 €$ \\
\hline $\begin{array}{c}\text { Investments } \mathrm{INV}_{1(4)} \text { for a tank with capacity } \mathrm{V}_{1(4)}=4 \mathrm{~m}^{3} \text { and dual water } \\
\text { supply installation }\end{array}$ & $3023 € \times 22=66,506 €$ \\
\hline $\begin{array}{c}\text { Investments } \mathrm{INV}_{1(5)} \text { for a tank with capacity } \mathrm{V}_{1(5)}=5 \mathrm{~m}^{3} \text { and dual water } \\
\text { supply installation }\end{array}$ & $3256 € \times 22=71,632 €$ \\
\hline $\begin{array}{c}\text { Investments } \mathrm{INV}_{2(15)} \text { for a tank with capacity } \mathrm{V}_{2(15)}=15 \mathrm{~m}^{3} \text { and dual water } \\
\text { supply installation }\end{array}$ & $63,279 €$ \\
\hline $\begin{array}{c}\text { Investments } \mathrm{INV}_{2(30)} \text { for a tank with capacity } \mathrm{V}_{2(30)}=30 \mathrm{~m}^{3} \text { and dual water } \\
\text { supply installation }\end{array}$ & $67,606 €$ \\
\hline $\begin{array}{c}\text { Investments } \mathrm{INV}_{2(45)} \text { for a tank with capacity } \mathrm{V}_{2(45)}=45 \mathrm{~m}^{3} \text { and dual water } \\
\text { supply installation }\end{array}$ & $71,933 €$ \\
\hline $\begin{array}{c}\text { Investments } \mathrm{INV}_{2(60)} \text { for a tank with capacity } \mathrm{V}_{2(60)}=60 \mathrm{~m}^{3} \text { and dual water } \\
\text { supply installation }\end{array}$ & $74,830 €$ \\
\hline $\begin{array}{c}\text { Investments } I N V_{2(75)} \text { for a tank with capacity } V_{2(70)}=75 \mathrm{~m}^{3} \text { and dual water } \\
\text { supply installation }\end{array}$ & $78,925 €$ \\
\hline \multicolumn{2}{|l|}{ Operating Cost } \\
\hline Purchase price for $1 \mathrm{~m}^{3}$ of tap water, $\mathrm{cw}_{\mathrm{t}}$ & $0.90 €$ \\
\hline Price for $1 \mathrm{~m}^{3}$ sewage, $\mathrm{cb}_{\mathrm{t}}$ & $1.39 €$ \\
\hline Purchase price of $1 \mathrm{KWh}$ of electricity, ce & $0.14 €$ \\
\hline Price for $1 \mathrm{~m}^{3}$ of rainwater, $\mathrm{cr}_{\mathrm{t}}$ & $0.70 €$ \\
\hline Annual increase in the price of tap water, iw & $2 \%$ \\
\hline Annual increase in sewage disposal prices, is & $2 \%$ \\
\hline Annual increase in rainwater drainage prices, id & $2 \%$ \\
\hline \multicolumn{2}{|l|}{ Other Parameters } \\
\hline Discount rate, $r$ & $5 \%$ \\
\hline Analysis period, $\mathrm{T}$ & 30 years \\
\hline
\end{tabular}

\section{Results and Discussion}

\subsection{Hydraulic Analysis}

Using the simulation model, hydraulic calculations of rainwater harvesting system operation for various tank capacities were performed for the adopted values of the calculation parameters. The results of the hydraulic calculations for Variant 1A, Variant 2A, Variant 1B, and Variant 2B are shown in Figure 4.

The calculations carried out show a significant relationship that occurs between the tank capacity and the volume of rainwater used in buildings and the amount of tap water and the amount of rainwater discharge outside the system. A comparison of the decentralized system with the centralized system, in the case of the variant where rainwater was used only for toilet flushing (Variant 1A and Variant 2A), no significant differences were observed in the amount of rainwater used for this purpose. For the smallest tank volumes in the systems analyzed, the difference in the amount of rainwater used was about $40 \mathrm{~m}^{3}$ per year, whereas for the largest tank volumes it was just $8 \mathrm{~m}^{3}$. The situation was similar for the case where rainwater was intended for toilet flushing and watering the garden. The differences between the systems were slightly larger, but they were still not significant. Greater water saving opportunities were noticed for the rainwater harvesting system installed individually 
for each building. Therefore, the question about the rational and financially justified capacity of the rainwater storage tank becomes relevant and this question is answered on the basis of an analysis of the system effectiveness which is determined on the basis of Formula (3). The results of calculating the effectiveness of the $E_{\mathrm{f}}$ system are shown in Figure 5.

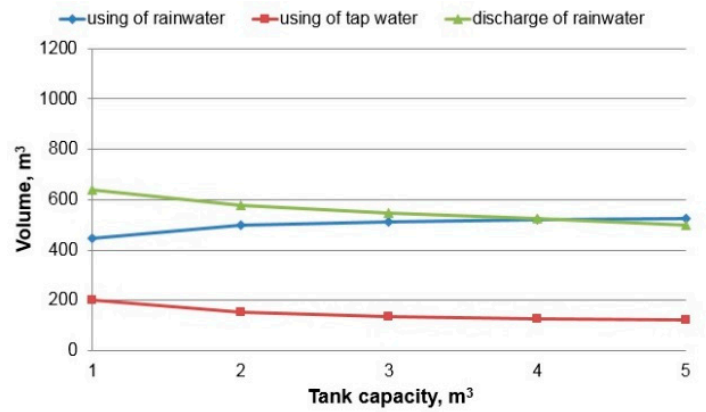

(a)

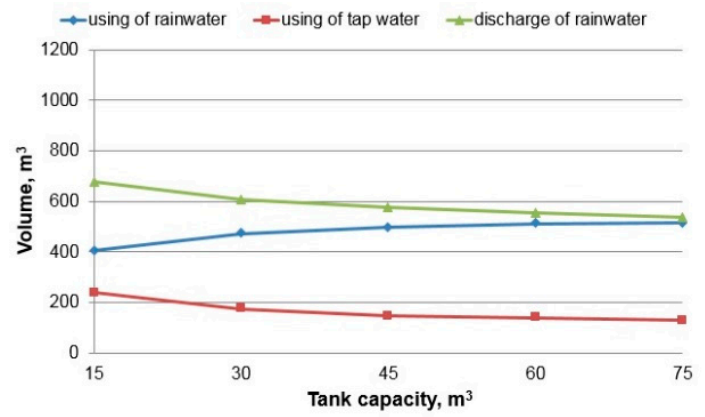

(c)

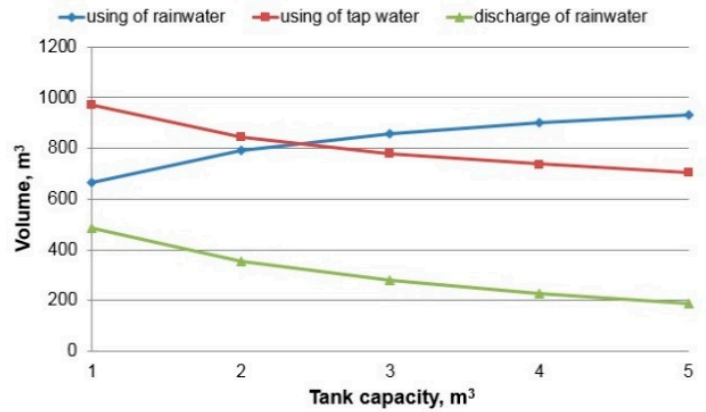

(b)

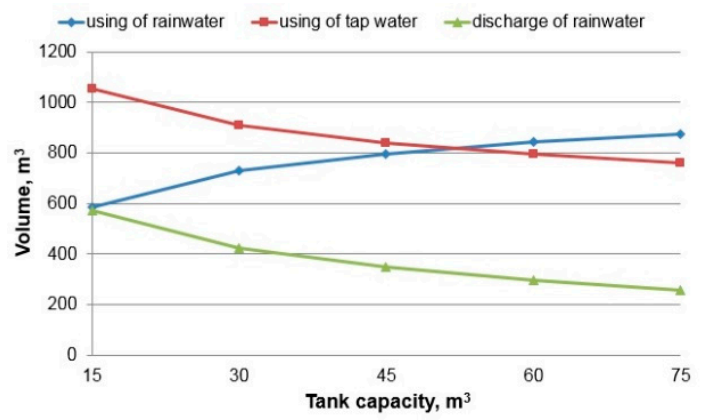

(d)

Figure 4. The average volume of rainwater discharged to the sewage network and tap water supplied to a RWHS for various storage tank capacities: (a) Variant 1A, (b) Variant 1B, (c) Variant 2A, and (d) Variant 2B.

According to the results of the calculations, it can be clearly observed that above a certain level of tank capacity, a significant increase does not determine a relevant growth in system efficiency. For a difference in the efficiency level of no more than $1 \%$, it can be assumed that the tank capacity would be optimal in terms of the use of rainwater. From the point of view of system efficiency, the most favorable capacities should be the following: The tank with capacity of $V=4 \mathrm{~m}^{3}$ for Variant $1 \mathrm{~A}$, the tank with capacity of $V=5 \mathrm{~m}^{3}$ for Variant $1 \mathrm{~B}$, the tank with capacity of $\mathrm{V}=60 \mathrm{~m}^{3}$ for Variant $2 \mathrm{~A}$, and the tank with capacity $V=75 \mathrm{~m}^{3}$ for Variant $2 \mathrm{~B}$. The average performance indicator over a multiannual period is $80 \%, 79 \%, 57 \%$, and $54 \%$ for Variants $1 \mathrm{~A}, 2 \mathrm{~A}, 1 \mathrm{~B}$, and $2 \mathrm{~B}$, respectively. The low level of efficiency for the last two variants is mainly due to the high demand for water, which is not covered by rainwater. Because there are such small differences in water savings that can be obtained by replacing it with rainwater, it is the financial analysis that should show which of the analyzed solutions for the rainwater harvesting systems (the decentralized or the centralized ones) is most beneficial for the housing estate considered. 


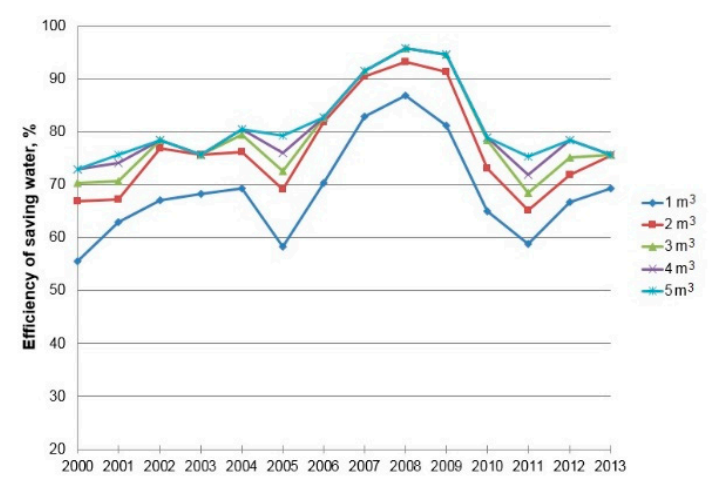

(a)

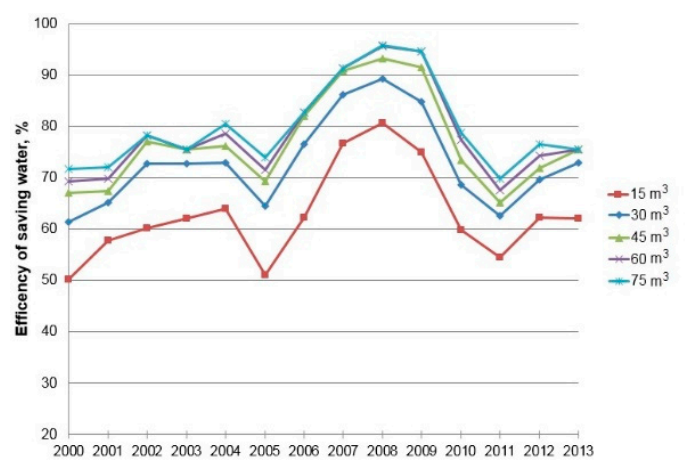

(c)

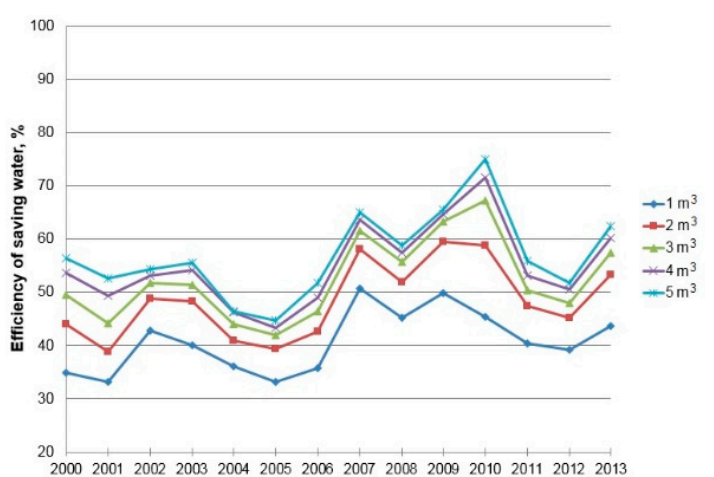

(b)

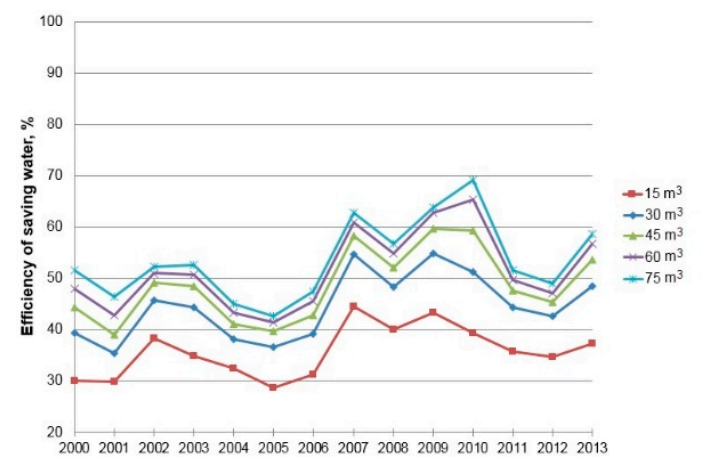

(d)

Figure 5. The efficiency of tap water saving using RWHS as a function of storage tank capacity:

(a) Variant 1A, (b) Variant 1B, (c) Variant 2A, and (d) Variant 2B.

\subsection{Financial Efficiency}

Calculations of the financial effectiveness of the investment for the adopted variants of the RWHS system were based on the results of hydraulic analyzes. Variant 0 was adopted as the comparative variant, in which no such system was used, and the buildings were supplied with water only from the water supply network. The LCC methodology was used in the analyzes. The results of calculations carried out according to Formulas (4)-(11) for the adopted variants of various reservoir retention capacities are presented in Figure 6.

The test results for various system configurations show that the amount of the LCC costs, and thus the cost-effectiveness of the use of individual variants, is significantly influenced by the capacity of the central tank or the capacity of individual tanks. In both Variant 1 and Variant 2, as the tank capacity increases, the share of INV investment costs in the total LCC costs increases.

On the basis of the results obtained from the life cycle cost analysis, it was found that none of the considered options involving the use of a RWHS is financially more favorable than Option 0, both in the decentralized and centralized system. Therefore, for such defined installation parameters from a financial point of view, none of them is justified. This result is primarily influenced by capital expenditure, which, depending on the system variant, accounted for $60 \%$ to $70 \%$ of the LCC value for Variant 1A and $41 \%$ to $52 \%$ for Variant $1 \mathrm{~B}$ for the decentralized system; and from $58 \%$ to $67 \%$ for Variant 2A and 39\% to $48 \%$ for Variant 2B for the rainwater harvesting system in a centralized system. The unfavorable financial result of the centralized and decentralized rainwater harvesting system is also influenced by the operating costs resulting from the purchase of water from the water supply network in the 30-year period analyzed. Savings resulting from replacing tap water with rainwater do not compensate for the costs necessary to carry out a RWHS. 


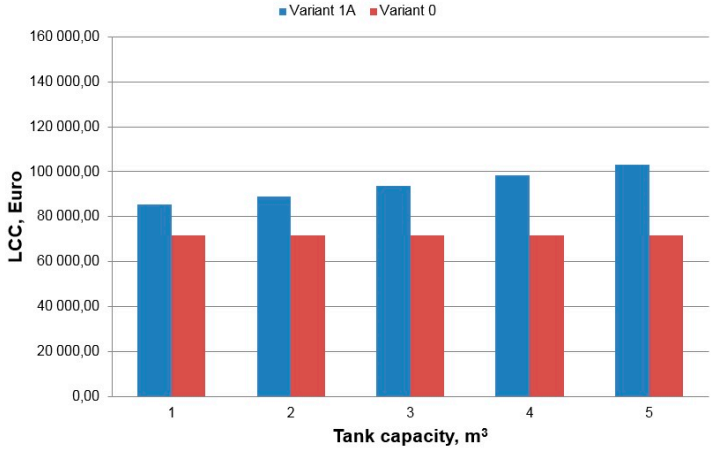

(a)

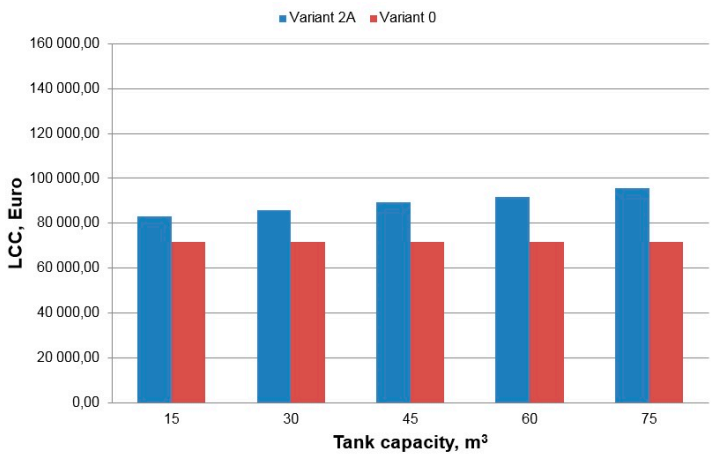

(c)

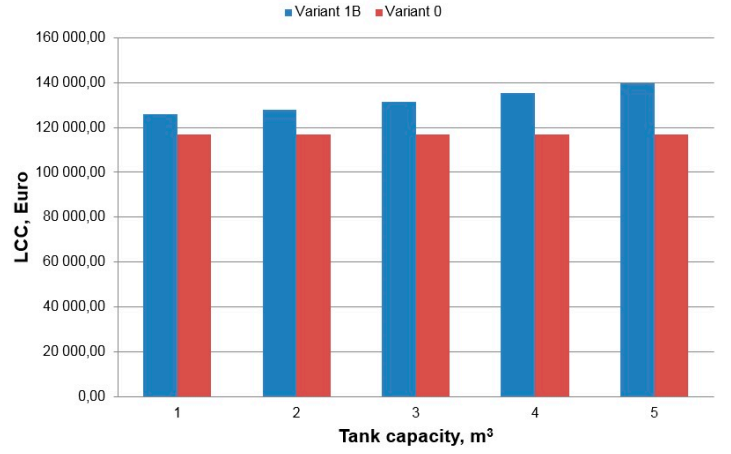

(b)

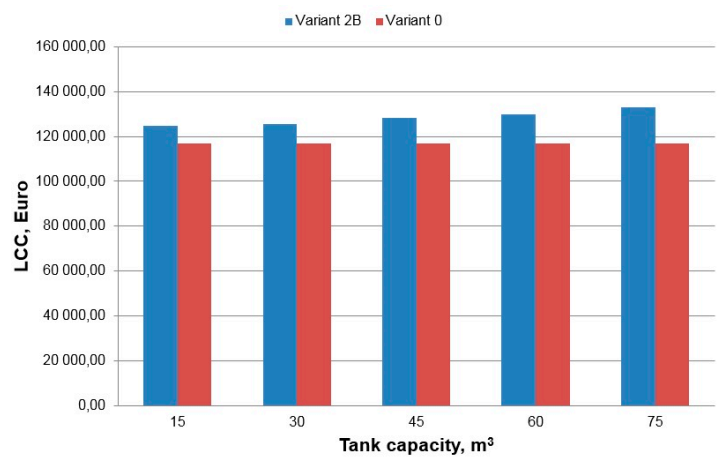

(d)

Figure 6. Life cycle cost for variants for 30 years of the analysis: (a) Variant 1A, (b) Variant 1B, (c) Variant 2A, and (d) Variant 2B.

Generally, it can be stated that the centralized rainwater harvesting system for the housing estate analyzed is financially more advantageous than the decentralized rainwater harvesting system, although the differences in the LCC costs were not significant. For the variant where rainwater was intended for toilet flushing, the LCC indicator for the smallest tank volumes $\left(1 \mathrm{~m}^{3}\right.$ and $\left.15 \mathrm{~m}^{3}\right)$ was only about 3\% lower for the centralized rainwater harvesting system. Similarly, this difference between the LCC costs for the centralized and decentralized systems for the largest tank volumes $\left(5 \mathrm{~m}^{3}\right.$ and 75 $\mathrm{m}^{3}$ ) was only $5 \%$ (Figure $6 \mathrm{a}, \mathrm{c}$ ). Considering the use of rainwater for toilet flushing and watering the garden (Variant 2A and Variant 2B), it was noticed that the difference in the level of LCC for the tank capacity of $1 \mathrm{~m}^{3}$ and $15 \mathrm{~m}^{3}$ was smaller than $1 \%$ (Figure $6 \mathrm{~b}, \mathrm{~d}$ ), and in the case of the largest tanks, this difference was at a similar level as in the situation when RWHS was intended only for toilet flushing.

In order to assess the impact of variable investment conditions on the financial effects, a sensitivity analysis was performed. The analysis involved examining the impact of future changes in the financial model parameters on the level of investment profitability. For this investment, the research was carried out according to three scenarios of changes in the model components within $\pm 25 \%$ of the costs determined for the base year. Considering the increase in unit prices of water, sewage, and energy in recent years, and the fact that the calculations had already taken into account the annual increase in unit prices, it was found that a larger decrease or increase in the value of operating costs was unlikely. The following change scenarios were adopted in the research:

- Scenario A, the change in the value of TOC operating costs resulting from changes in the prices of tap water and sanitary sewage discharged from the building to the sewage network;

- Scenario $\mathrm{B}$, the change in the value of $\mathrm{OC}_{\mathrm{kt}}$ operating costs resulting from changes in electricity prices; 
- Scenario $\mathrm{C}$, the change in the value of $\mathrm{OC}_{\mathrm{kt}}$ operating costs resulting from changes in prices for rainwater drainage to the drainage network.

Graphical interpretations of the results from the test outcomes are presented in Figures 7 and 8 , and show that for all variants and the entire range of design parameters, assuming the use of rainwater, no significant improvements were observed in the efficiency of variants as compared to the traditional water system solution (Variant 0 ). When analyzing the impact of lowering operating costs on the value of LCC costs, it was noticed that the largest decrease in the LCC ratio in relation to its base value was in Scenario A for variants where the rainwater harvesting system was intended for toilet flushing and garden watering (Figure $7 \mathrm{~b}, \mathrm{~d}$ ). Reduction of the cost of purchasing water and wastewater disposal by $25 \%$, in this case, reduce the total costs in the range of $10 \%\left(5 \mathrm{~m}^{3}\right.$ tank) to $12.5 \%$ ( $1 \mathrm{~m}^{3}$ tank) for the decentralized system and $11 \%\left(75 \mathrm{~m}^{3}\right.$ tank) to $13 \%\left(15 \mathrm{~m}^{3}\right.$ tank) for the centralized system.

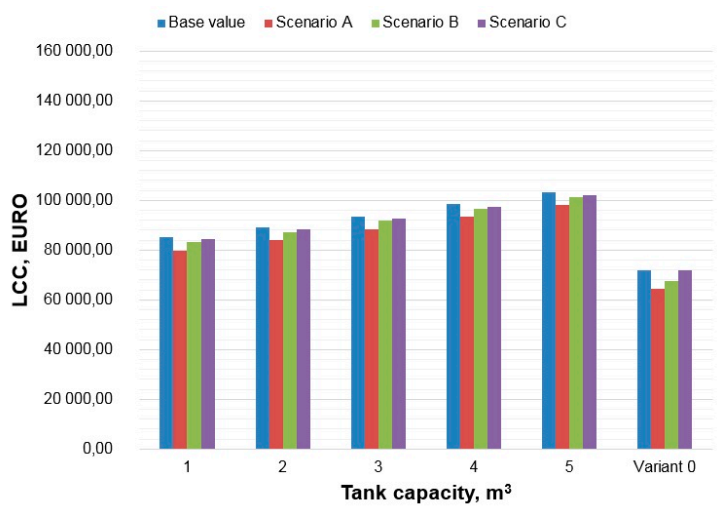

(a)

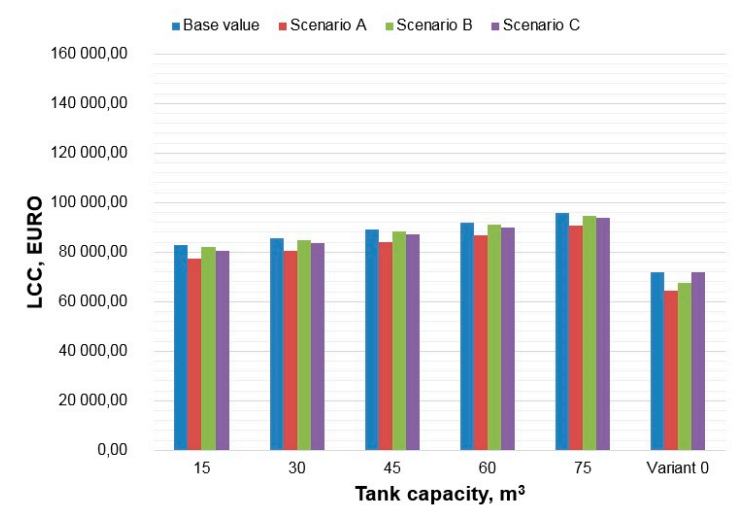

(c)

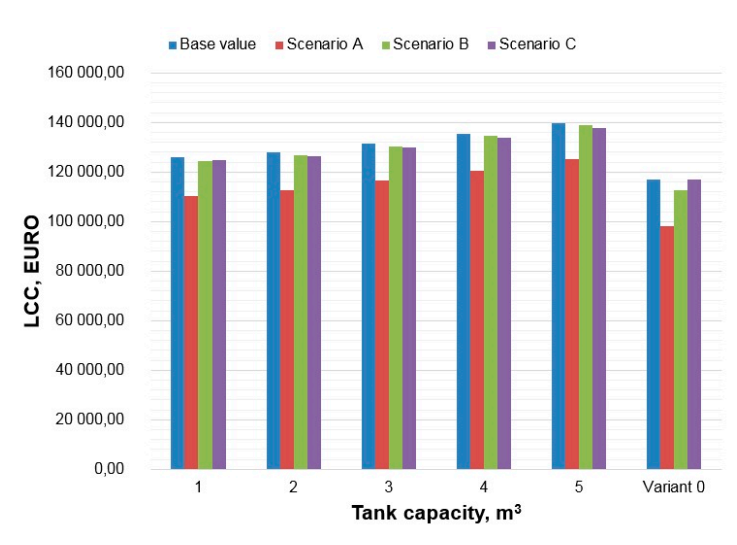

(b)

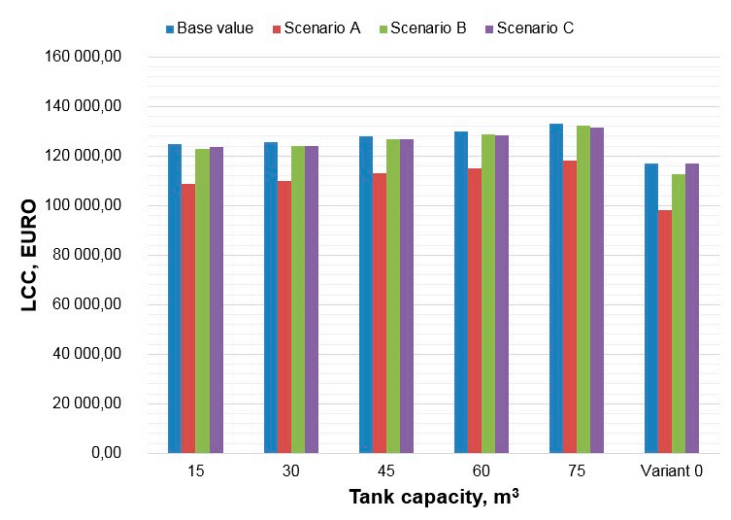

(d)

Figure 7. The impact of reducing operating costs by $25 \%$ on LCC costs according to the change scenarios

(a) Variant 1A, (b) Variant 1B, (c) Variant 2A, and (d) Variant 2B.

Similarly, when operating costs increased by $25 \%$, the greatest impact was observed for Scenario A and the use of RWHS for toilet flushing and for watering the garden, both in a decentralized and centralized systems (Figure 8b,d). The lowest impact was visible for the changes in costs according to Scenario B, and similar to the variants with RWHS these costs resulted only from the discharge of excess rainwater to the sewage system. 


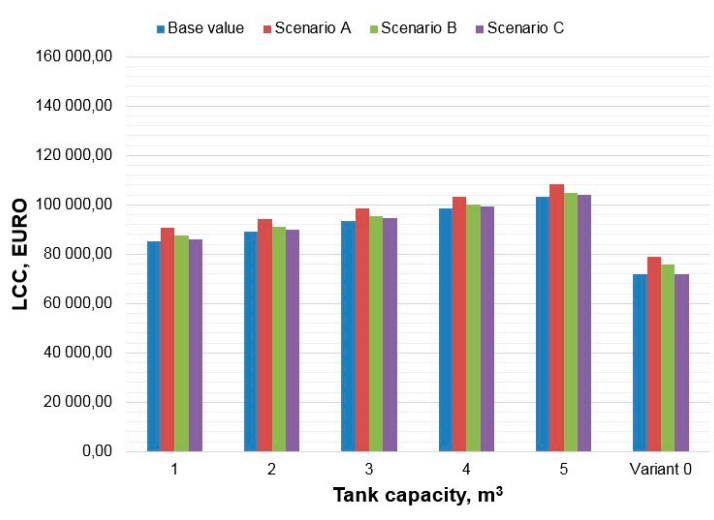

(a)

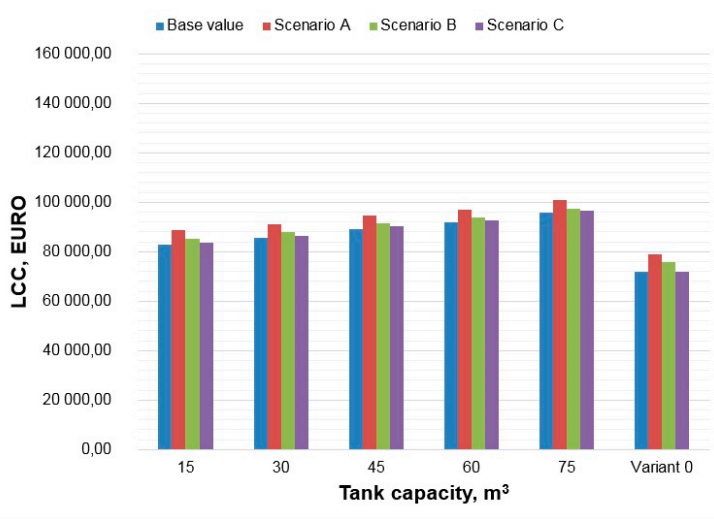

(c)

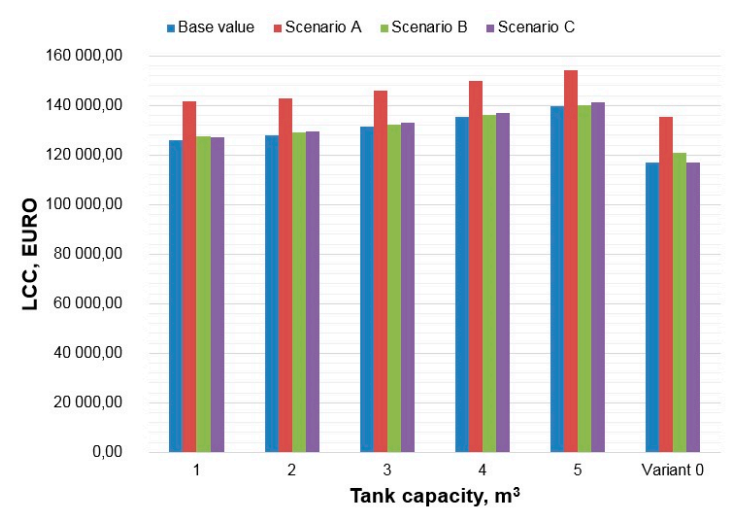

(b)

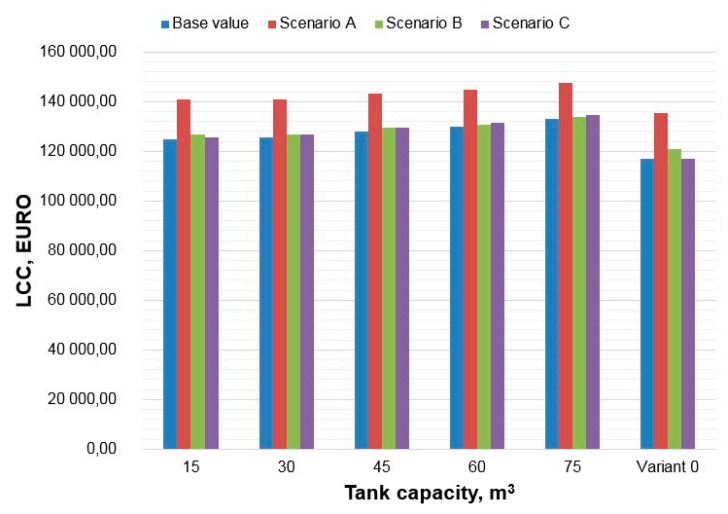

(d)

Figure 8. The impact of a $25 \%$ increase in operating costs on LCC costs according to the change scenarios (a) Variant 1A, (b) Variant 1B, (c) Variant 2A, and (d) Variant 2B.

Taking into consideration the results based on the sensitivity analysis and the high share of INV investments in the total LCC costs, this research was carried out to determine the level of cofinancing needed to implement the systems and allow the investments to be profitable. Currently, in Poland, there are very few examples of cities where residents can receive such funding. The results of this research in this area are shown in Figure 9. In the case of the decentralized system and the use of rainwater only for toilet flushing (Variant 1A), 25\% cofinancing does not affect the profitability of the investment, therefore, the application of RWHS is more favorable than Variant 0 (Figure 9a). In the case of Variant 1B, where rainwater was used in addition to watering the garden, reducing the INV by $25 \%$ results in a slight reduction in the LCC costs below the total costs of Variant 0 , but only for the tank volumes of $1 \mathrm{~m}^{3}, 2 \mathrm{~m}^{3}$, and $3 \mathrm{~m}^{3}$ (Figure 9b). For Variant $1 \mathrm{~A}$ and Variant $1 \mathrm{~B}$, the $50 \%$ cofinancing significantly reduces the LCC in relation to its base value. Depending on the tank capacity, this reduction ranges from $30 \%$ to $35 \%$ of the LCC costs for Variant $1 \mathrm{~A}$ and from $20 \%$ to $26 \%$ for Variant 1B. 


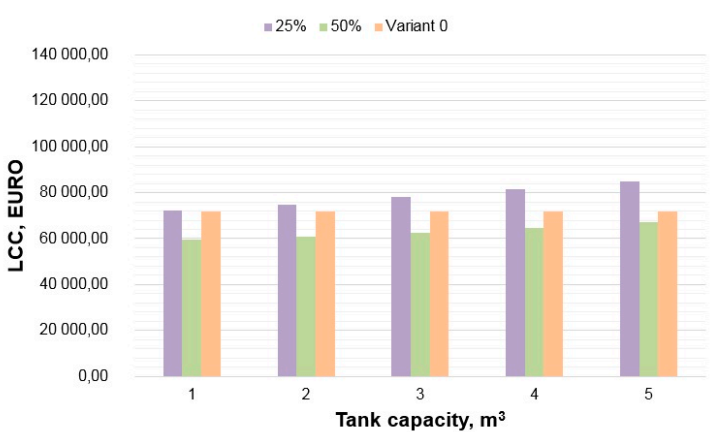

(a)

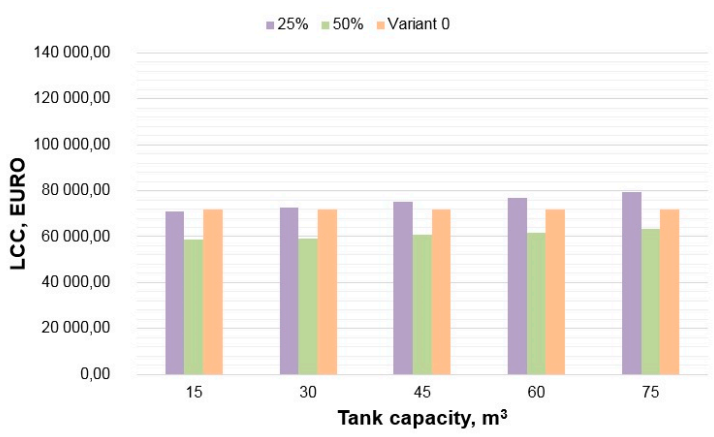

(c)

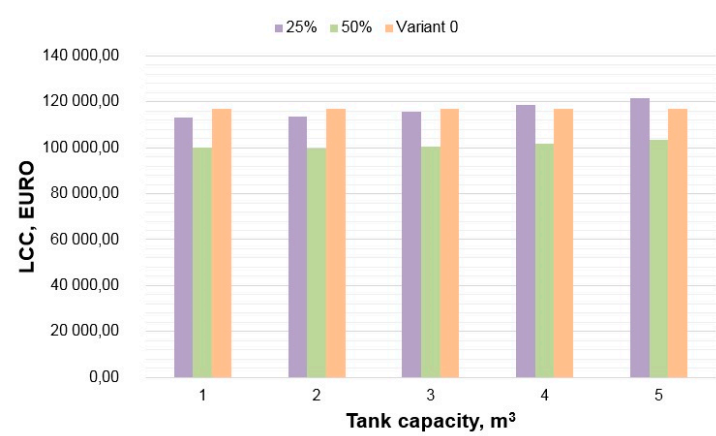

(b)

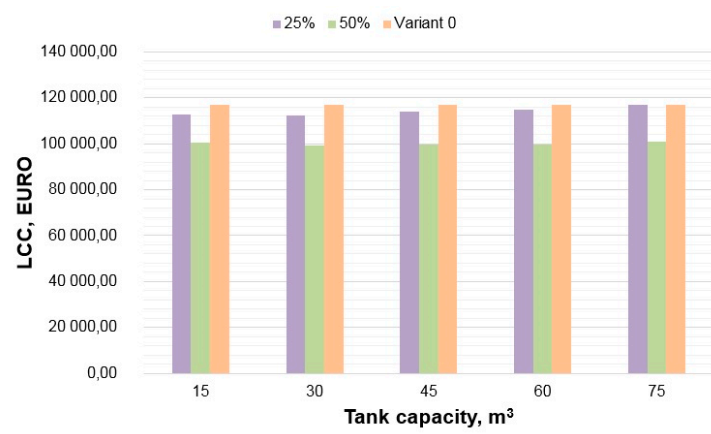

(d)

Figure 9. The impact of cofinancing for investments on the LCC costs: (a) Variant 1A, (b) Variant 1B, (c) Variant 2A, and (d) Variant 2B.

In the case of the centralized rainwater harvesting system and Variant $2 \mathrm{~A}$, the subsidies for initial investments of $25 \%$ of their value only for a $15 \mathrm{~m}^{3}$ capacity tank would reduce the total investments slightly below the level of these costs for Variant 0 (Figure 9c). In addition, for Variant 2B, the LCC cost differences between Variant 0 and the solutions from RWHS were insignificant. As in the decentralized system, a visible improvement in financial conditions of investments is only observed at a $50 \%$ reduction of the INV. The LCC costs were reduced from $29 \%$ to $33 \%$ for Variant $2 \mathrm{~A}$ and from $19 \%$ to $24 \%$ for Variant $2 \mathrm{~B}$ as compared with the base value of these costs.

\section{Conclusions}

The aim of this study was to compare centralized and decentralized rainwater harvesting systems in terms of their hydraulic and financial efficiency. The analysis was carried out for a real estate development of single-family houses located in Poland.

The obtained research results showed that the efficiency of the RWHS depended mainly on the demand for non-potable water and the amount of rainwater flowing into the system, and to a lesser extent on the system layout (centralized or decentralized). In variants, where rainwater was only used to flush toilets, the water saving efficiency was $80 \%$ and $79 \%$ for decentralized and centralized RWHSs, respectively. The use of rainwater for toilet flushing and watering the garden resulted in a significant reduction in efficiency to $57 \%$ (the decentralized system) and $54 \%$ (the centralized system).

The results of the life cycle cost analysis clearly showed that in spite of the reduction of reducing tap water consumption, neither the centralized nor the decentralized rainwater harvesting system was a financially viable solution for the housing estate in question. This was also confirmed by the sensitivity analysis that was conducted. Such unfavorable outcomes resulted from the amount of investments which in some variants constituted even $70 \%$ of the total LCC costs. Therefore, the cofinancing of such investments significantly improved their financial indicators. Depending on the tank capacity, the reduction of investments by $50 \%$ resulted in a maximum reduction in LCC costs from $29 \%$ to $33 \%$ for the centralized rainwater harvesting system and from $30 \%$ to $35 \%$ for the decentralized one. 
On the basis of the results of this research an important conclusion, which is also appropriate for other countries, can be drawn which is that in order to introduce sustainable management strategies and protection of water resources with a noticeable impact on the environment, it is necessary to raise public awareness, and above all, financial support, to encourage potential investors to implement decentralized or centralized alternative water installations.

Author Contributions: Conceptualization, D.S. and A.S.; methodology, D.S. and A.S.; software, D.S.; validation, D.S. and A.S.; formal analysis, D.S. and A.S.; investigation, D.S. and A.S.; resources, A.S.; data curation, D.S. and A.S.; writing — original draft preparation, A.S.; writing—-review and editing, A.S.; visualization, D.S. and A.S.; supervision, D.S. All authors have read and agreed to the published version of the manuscript.

Funding: This research received no external funding.

Conflicts of Interest: The authors declare no conflict of interest.

\section{References}

1. United Nations, Department of Economic and Social Affairs, Population Division. World Urbanization Prospects: The 2014 Revision, Highlights; United Nations, Department of Economic and Social Affairs, Population Division: New York, NY, USA, 2014.

2. Trasviña-Carrillo, J.; Wurl, J.; Imaz-Lamadrid, M. Groundwater Flow Model and Statistical Comparisons Used in Sustainability of Aquifers in Arid Regions. Resources 2019, 8, 134. [CrossRef]

3. Sim, L.; Onishi, A.; Gervais, O.; Chan, N. Comparative Research on River Basin Management in the Sagami River Basin (Japan) and the Muda River Basin (Malaysia). Resources 2018, 7, 33. [CrossRef]

4. Bettili, L.; Pek, E.; Salman, M. A Decision Support System for Water Resources Management: The Case Study of Mubuku Irrigation Scheme, Uganda. Sustainability 2019, 11, 6260. [CrossRef]

5. Boyle, T.; Giurco, D.; Mukheibir, P.; Liu, A.; Moy, C.; White, S.; Stewart, R. Intelligent metering for urban water: A review. Water 2013, 5, 1052-1081. [CrossRef]

6. Tchórzewska-Cieślak, B.; Pietrucha-Urbanik, K.; Papciak, D. An Approach to Estimating Water Quality Changes in Water Distribution Systems Using Fault Tree Analysis. Resources 2019, 8, 162. [CrossRef]

7. Pietrucha-Urbanik, K.; Tchórzewska-Cieślak, B. Approaches to Failure Risk Analysis of the Water Distribution Network with Regard to the Safety of Consumers. Water 2018, 10, 1679. [CrossRef]

8. Gou, Z.; Prasad, D.; Siu-Yu Lau, S. Are green buildings more satisfactory and comfortable? Habitat Int. 2013, 39, 156-161. [CrossRef]

9. US EPA. Definition of Green Building; U.S. Environmental Protection Agency: Washington, DC, USA, 2009.

10. Diamond, R.C.; Ye, Q.; Feng, W.; Yan, T.; Mao, H.; Li, Y.; Guo, Y.; Wang, J. Sustainable Building in China-A Green Leap Forward? Buildings 2013, 3, 639-658. [CrossRef]

11. Pomares, J.C.; González, A.; Saura, P. Simple and Resistant Construction Built with Concrete Voussoirs for Developing Countries. J. Constr. Eng. Manag. 2018, 144. [CrossRef]

12. Willuweit, L.; O'Sullivan, J. A decision support tool for sustainable planning of urban water systems: Presenting the Dynamic Urban Water Simulation Model. Water Res. 2013, 47, 7206-7220. [CrossRef]

13. United Nation. Transforming Our World: The 2030 Agenda for Sustainable Development. Available online: https://sustainabledevelopment.un.org/post2015/transformingourworld (accessed on 10 November 2019).

14. Directive 2000/60/EC of the European Parliament and of the Council of 23 October 2000 Establishing a Framework for Community Action in the Field of Water Policy; European Environment Agency: Copenhagen, Denmark, 2000.

15. Kordana, S.; Pochwat, K.; Słyś, D.; Starzec, M. Opportunities and Threats of Implementing Drain Water Heat Recovery Units in Poland. Resources 2019, 8, 88. [CrossRef]

16. Kordana, S. SWOT analysis of wastewater heat recovery systems application. E3S Web Conf. 2017, 17, 00042. [CrossRef]

17. Bocanegra-Martínez, A.; Ponce-Ortega, J.M.; Nápoles-Rivera, F.; Serna-González, M.; Castro-Montoya, A.J.; El-Halwagi, M.M. Optimal design of rainwater collecting systems for domestic use into a residential development. Resour. Conserv. Recycl. 2014, 84, 44-56. [CrossRef]

18. Takagi, K.; Otaki, M.; Otaki, Y. Potential of Rainwater Utilization in Households Based on the Distributions of Catchment Area and End-Use Water Demand. Water 2018, 10, 1706. [CrossRef] 
19. Lani, N.H.; Yusop, Z.; Syafiuddin, A. A review of rainwater harvesting in Malaysia: Prospects and challenges. Water 2018, 10, 506. [CrossRef]

20. Zdeb, M.; Zamorska, J.; Papciak, D. Studying Microbiology of Rain Water for of Their Use in Economy. J. Ecol. Eng. 2016, 17, 203-208. [CrossRef]

21. Zdeb, M.; Papciak, D.; Zamorska, J. An assessment of the quality and use of rainwater as the basis for sustainable water management in suburban areas. E3S Web Conf. 2018, 45, 00111. [CrossRef]

22. Lee, J.Y.; Bak, G.; Han, M. Quality of roof-harvested rainwater-comparison of different roofing materials. Environ. Pollut. 2012, 162, 422-429. [CrossRef]

23. Teston, A.; Geraldi, M.S.; Colasio, B.M.; Ghisi, E. Rainwater Harvesting in Buildings in Brazil: A Literature Review. Water 2018, 10, 471. [CrossRef]

24. Jacoby Cureau, R.; Ghisi, E. Reduction of PotableWater Consumption and Sewage Generation on a City Scale: A Case Study in Brazil. Water 2019, 11, 2351. [CrossRef]

25. Unami, K.; Mohawesh, O.; Sharifi, E.; Takeuchi, J.; Fujihara, M. Stochastic modelling and control of rainwater harvesting systems for irrigation during dry spells. J. Clean. Prod. 2015, 88, 185-195. [CrossRef]

26. Słyś, D.; Stec, A.; Zelenakova, M. A LCC analysis of rainwater management variants. Ecol. Chem. Eng. S 2012, 19, 359-372. [CrossRef]

27. Kaposztasova, D.; Vranayova, Z.; Markovic, G.; Purcz, P. Rainwater Harvesting, Risk Assessment and Utilization in Kosice-City, Slovakia. Procedia Eng. 2014, 89, 1500-1506. [CrossRef]

28. Rahman, A.; Dbais, J.; Imteaz, M. Sustainability of rainwater harvesting systems in multistorey residential buildings. Am. J. Appl. Sci. 2010, 3, 889-898. [CrossRef]

29. Cipolla, S.; Altobelli, M.; Maglionico, M. Decentralized Water Management: Rainwater Harvesting, Greywater Reuse and Green Roofs within the GST4Water Project. Proceedings 2018, 2, 673. [CrossRef]

30. Yan, X.; Ward, S.; Butler, D.; Daly, B. Performance assessment and life cycle analysis of potable water production from harvested rainwater by a decentralized system. J. Clean. Prod. 2018, 172, 2167-2173. [CrossRef]

31. Gurung, T.; Sharma, A. Communal rainwater tank systems design and economies of scale. J. Clean. Prod. 2014, 67, 26-36. [CrossRef]

32. Freni, G.; Liuzzo, L. Effectiveness of Rainwater Harvesting Systems for Flood Reduction in Residential Urban Areas. Water 2019, 11, 1389. [CrossRef]

33. Zavala, M.L.; Vega, R.C.; Miranda, R.L. Potential of Rainwater Harvesting and Greywater Reuse for Water Consumption Reduction and Wastewater Minimization. Water 2016, 8, 264. [CrossRef]

34. Palla, A.; Gneco, I.; La Barbera, P. The impact of domestic rainwater harvesting systems in storm water runoff mitigation at the urban block scale. J. Environ. Manag. 2017, 191, 297-305. [CrossRef]

35. Starzec, M.; Dziopak, J.; Sły’s, D.; Pochwat, K.; Kordana, S. Dimensioning of Required Volumes of Interconnected Detention Tanks Taking into Account the Direction and Speed of Rain Movement. Water 2018, 10, 1826. [CrossRef]

36. Starzec, M. A critical evaluation of the methods for the determination of required volumes for detention tank. E3S Web Conf. 2018, 45, 00088. [CrossRef]

37. Moniruzzaman, M.; Imteaz, M.A. Generalized equations, climatic and spatial variabilities of potential rainwater savings: A case study for Sydney. Resour. Conserv. Recycl. 2017, 125, 139-156. [CrossRef]

38. Amos, C.; Rahman, A.; Mwangi Gathenya, J. Economic Analysis and Feasibility of Rainwater Harvesting Systems in Urban and Peri-Urban Environments: A Review of the Global Situation with a Special Focus on Australia and Kenya. Water 2016, 8, 149. [CrossRef]

39. Imteaz, M.A.; Paudel, U.; Ahsan, A.; Santos, C. Climatic and spatial variability of potential rainwater savings for a large coastal city. Resour. Conserv. Recycl. 2015, 105, 143-147. [CrossRef]

40. Ghimire, S.R.; Johnston, J.M.; Ingwersen, W.W.; Hawkins, T. Life Cycle Assessment of Domestic and Agricultural Rainwater Harvesting Systems. Environ. Sci. Technol. 2014, 48, 4069-4077. [CrossRef]

41. Ghisi, E.; Rupp, R.F.; Triska, Y. Comparing indicators to rank strategies to save potable water in buildings. Resour. Conserv. Recycl. 2014, 87, 137-144. [CrossRef]

42. Kisakye, V.; Van der Bruggen, B. Effects of climate change on water savings and water security from rainwater harvesting systems. Resour. Conserv. Recycl. 2018, 138, 49-63. [CrossRef]

43. Liang, X.; Van Dijk, M.P. Economic and financial analysis on rainwater harvesting for agricultural irrigation in the rural areas of Beijing. Resour. Conserv. Recycl. 2011, 55, 1100-1108. [CrossRef] 
44. Leong, J.; Chong, M.; Poh, P.; Vieritz, A.; Talei, A.; Chow, M. Quantification of mains water savings from decentralised rainwater, greywater, and hybrid rainwater-greywater systems in tropical climatic conditions. J. Clean. Prod. 2018, 176, 946-958. [CrossRef]

45. Imteaz, M.A.; Moniruzzaman, M. Spatial variability of reasonable government rebates for rainwater tank installations: A case study for Sydney. Resour. Conserv. Recycl. 2018, 133, 112-119. [CrossRef]

46. Roebuck, R.M.; Oltean-Dumbrava, C.; Tait, S. Whole life cost performance of domestic rainwater harvesting systems in the United Kingdom. Water Environ. J. 2011, 25, 355-365. [CrossRef]

47. Walczykiewicz, T. Scenarios of Water Resources Development in Poland up to 2030. Water Resour. 2014, 41, 763-773. [CrossRef]

48. Oremo, F.; Mulwa, R.; Oguge, N. Knowledge, Attitude and Practice in Water Resources Management among Smallholder Irrigators in the Tsavo Sub-Catchment, Kenya. Resources 2019, 8, 130. [CrossRef]

49. Pavlik, D.; Söhl, D.; Pluntke, T.; Bernhofer, C. Climate change in the Western Bug river basin and the impact on future hydro-climatic conditions. Environ. Earth Sci. 2014, 72, 4787-4799. [CrossRef]

50. Stec, A.; Zelenáková, M. An Analysis of the Effectiveness of Two Rainwater Harvesting Systems Located in Central Eastern Europe. Water 2019, 11, 458. [CrossRef]

51. Słyś, D.; Stec, A. The analysis of variants of water supply systems in multi-family residential building. Ecol. Chem. Eng. S 2014, 21, 623-635. [CrossRef]

52. Fewkes, A. Modelling the performance of rainwater collection systems: Towards a generalised approach. Urban Water 2000, 1, 323-333. [CrossRef]

53. ISAP. Rozporzadzenie Ministra Infrastruktury z Dnia 14 Stycznia 2002 r. w Sprawie Przeciętnych Norm Zużycia Wody (Dz. U. 2002 Nr 8, poz. 70); ISAP: Warsaw, Poland, 2002.

54. EurEau. Europe's Water in Figures; An Overview of the European Drinking Water and Waste Water Sectors; European Federation of National Associations of Water Services: Brussels, Belgium, 2017.

55. Słyś, D. Potential of rainwater utilization in residential housing in Poland. Water Environ. J. 2009, 23, 318-325. [CrossRef]

56. Palla, A.; Gnecco, I.; Lanza, L.G.; La Barbera, P. Performance analysis of domestic rainwater harvesting systems under various European climate zones. Resour. Conserv. Recycl. 2012, 62, 71-80. [CrossRef]

57. Silva, C.; Sousa, V.; Carvalho, N. Evaluation of rainwater harvesting in Portugal: Application tosingle-family residences. Resour. Conserv. Recycl. 2015, 94, 21-34. [CrossRef]

58. Fuller, S.; Petersen, S. NIST Handbook 135-Life Cycle Costing Manual for the Federal Energy Management Program; National Institute of Standards and Technology, The U.S. Department of Energy: Washington, DC, USA, 1996. Available online: www.fire.nist.gov/bfrlpubs/build96/PDF/b96121.pdf (accessed on 10 November 2019).

59. Spickova, M.; Myskova, R. Costs Effciency Evaluation Using Life Cycle Costing as Strategic Method. Procedia Econ. Financ. 2015, 34, 337-343. [CrossRef]

60. Bierer, A.; Götze, U.; Meynerts, L.; Sygulla, R. Integrating life cycle costing and life cycle assessment using extended material flow cost accounting. J. Clean. Prod. 2015, 108, 1289-1301. [CrossRef]

61. DOE. Life Cycle Cost Handbook. Guidance for Life Cycle Cost Estimation and Analysis; Office of Acquisition and Project Management, U.S. Department of Energy: Washington, DC, USA, 2014. Available online: www. energy.gov/sites/prod/files/2014/10/f18/LCC\%20Handbook\%20Final\%20Version\%209-30-14.pdf (accessed on 10 November 2019).

62. Rahman, A.; Keane, J.; Imteaz, A.M. Rainwater harvesting in Greater Sydney: Water savings, reliability and economic benefits. Resour. Conserv. Recycl. 2012, 61, 16-21. [CrossRef]

63. Morales-Pinzón, T.; Lurueña, R.; Rieradevall, J.; Gasol, C.M.; Gabarrell, X. Financial feasibility and environmental analysis of potential rainwater harvesting systems: A case study in Spain. Resour. Conserv. Recycl. 2012, 69, 130-140. [CrossRef]

(C) 2020 by the authors. Licensee MDPI, Basel, Switzerland. This article is an open access article distributed under the terms and conditions of the Creative Commons Attribution (CC BY) license (http://creativecommons.org/licenses/by/4.0/). 